\title{
Correction to: Understanding the care and support needs of older people: a scoping review and categorisation using the WHO international classification of functioning, disability and health framework (ICF)
}

Sarah Abdi ${ }^{1}$, Alice Spann ${ }^{1}$, Jacinta Borilovic ${ }^{2}$, Luc de Witte ${ }^{1}$ and Mark Hawley ${ }^{1 *}$

\section{Correction to: BMC Geriatr}

https://doi.org/10.1186/s12877-019-1189-9

Following publication of the original article [1], we have been notified that acknowledgement should be added to the text of the articles. The Acknowledgement section should read as follows:

The authors gratefully acknowledge the support of the Economic \& Social Research Council (award ES/ P009255/1, Sustainable Care: connecting people and systems, 2017-21, Principal Investigator Sue Yeandle, University of Sheffield). Prof Mark Hawley is a Theme Lead for the National Institute for Health Research (NIHR) Devices for Dignity MedTech Cooperative (MIC). The work of the Devices for Dignity MIC is funded by the NIHR. The views expressed are those of the authors and not necessarily those of the NHS, the NIHR or the Department of Health and Social Care.

\section{Author details}

${ }^{1}$ Centre for Assistive Technology and Connected Healthcare, School of Health and Related Research, The Innovation Centre, The University of Sheffield, 217 Portobello, Sheffield S1 4DP, UK. ${ }^{2}$ Aging and Health Research Unit, Faculty of Health Sciences, The University of Sydney, 75 East Street, J block, Lidcombe, NSW 2141, Australia.
Published online: 22 January 2020

\section{Reference}

1. Abdi, et al. Understanding the care and support needs of older people: a scoping review and categorisation using the WHO international classification of functioning, disability and health framework (ICF). BMC Geriatr. 2019;19:195. https://doi.org/10.1186/s12877-019-1189-9.

Full list of author information is available at the end of the article

(c) The Author(s). 2020 Open Access This article is distributed under the terms of the Creative Commons Attribution 4.0 International License (http://creativecommons.org/licenses/by/4.0/), which permits unrestricted use, distribution, and reproduction in any medium, provided you give appropriate credit to the original author(s) and the source, provide a link to the Creative Commons license, and indicate if changes were made. The Creative Commons Public Domain Dedication waiver (http://creativecommons.org/publicdomain/zero/1.0/) applies to the data made available in this article, unless otherwise stated. 